\title{
A NEW SPECIES OF ONISCIGASTRID MAYFLY FROM TASMANIA, TASMANOPHLEBIA LOTIS, WITH COMMENTS ON THE AUSTRALIAN ONISCIGASTRID SPECIES
}

\author{
by Ronald E. Thresher \\ (with three text-figures, five plates and an appendix)
}

\begin{abstract}
Thresher, R.E. 2016 (15:xii): A new species of Oniscigastrid mayfly from Tasmania, Tasmanophlebia lotis, with comments on the Australian Oniscigastrid species. Papers and Proceedings of the Royal Society of Tasmania 150(2): 43-57. https://doi.org/10.26749/rstpp.150.2.43 ISSN 0080-4703. 50 Bramble Street, Ridgeway, Tasmania 7054, Australia. Email: ronaldethresher@gmail.com
\end{abstract}

\begin{abstract}
Imagoes, sub-imagoes and nymphs of a new species of Tasmanian mayfly (Tasmanophlebia lotis sp.nov.) are described based on morphological, ecological and genetic differences between it, the only other known Tasmanian species in the genus (T. lacustris) and congeneric species on the Australian mainland. Tasmanophlebia lotis is widely distributed in rivers at low elevations across the island, in contrast to $T$. lacustris, which is found in high-altitude lentic habitats. The separation of mainland Australian and Tasmanian species of Tasmanophlebia is consistent with similar observations based on genetic analysis of other Australian mayflies, and suggests differentiation well prior to the flooding of Bass Strait during Holocene deglaciation.
\end{abstract}

Key Words: CO1 mitochondrial DNA, genetics, imago, mating behaviour, nymph, sub-imago, Tasmanophlebia lotis.

\section{INTRODUCTION}

The mayfly family Oniscigastridae is represented in Australia by three described species, all in the genus Tasmanophlebia (Hubbard \& Campbell 1996). All are large and conspicuous, and often of importance to recreational fishers (e.g., Scholes 1961). In Tasmania, only one species has been described, Tasmanophlebia lacustris Tillyard, 1921 (see also Tillyard 1935), from adult imagoes and sub-imagoes collected from lakes on the Central Plateau (hence the common name, highland spinner) (Tillyard 1921). Subsequently, Riek (1955, p. 269), in his review of the family as it was then considered (Siphlonuridae, subfamily Siphlonurinae), noted first, that the genus was "well represented in the lakes and streams at high altitudes...in Tasmania" and second, that there was a degree of variability in a few features in T. lacustris, including differences among individuals in the position that the MP vein forks in the hind wing and in the shape of the claspers. More recently, Scholes (1961, p. 66), in a popular book on fly-fishing in Tasmania, reported collecting an "as yet unrecorded" species of Siphlonuridae from the South Esk River (northeast Tasmania), describing it as similar to T. lacustris, but smaller and in the sub-imago having a "curved bar of clear space....across both sets of wings". He further describes the general colouring of both the sub-imago ("pale grey") and imago ("dark olive brown above, ...underside paler, ....wings are glassy-clear").

In 1988, I collected sub-imagoes of a Tasmanophlebia from the Ringarooma River (also in northeast Tasmania) and the Styx River (southern Tasmania). Subsequent collections indicate, first, that the insect is broadly distributed in fast-flowing lowland rivers throughout Tasmania (see below); second, that they match the description given by Scholes (1961) for specimens from the South Esk River; and third, that they are very similar to a described mainland species, T. nigrescens. In that regard, the Museum of Victoria (MoV) holds a number of specimens collected in northern Tasmanian streams that are attributed to T. nigrescens, while Suter (1980) reported another mainland species, T. lacus-coerulei, as present in northern Tasmanian rivers.

In this paper, I describe the insect as a new species, Tasmanophlebia lotis sp. nov., on the basis of conspicuous morphological differences between it and the only other previously reported Tasmanian species, T. lacustris, and a CO1 genetic analysis (see Hebert et al. 2003). Information is also provided on the general biology of the two Tasmanophlebia species in Tasmania.

\section{MATERIALS AND METHODS}

Procedures for measuring and describing specimens broadly follow Suter (1986). Mayfly systematics follows Hubbard (1990). Protocols for genetic analysis broadly follow Folmer et al. (1994). DNA samples were extracted using phenol/ chloroform with precipitation from the aqueous solution using ethanol and $\mathrm{a} C \mathrm{CAB}$ (hexadecyltrimethylammonium bromide) protocol modified according to Grewe et al. (1993). The cytochrome c oxidase subunit 1 (CO1) region was amplified from all isolates by polymerase chain reaction (PCR) using the primers $\mathrm{HCO} 2198$ (5'-TAAACTTCAGGGTGACCAAAAAATCA-3') and LCOI490 (5'-GGTCAACAAATCATAAA GATATTGG-3') (Folmer et al. 1994). The DNA was denatured at $94^{\circ} \mathrm{C}$ for 15 seconds, primers annealed at $50^{\circ} \mathrm{C}$ for 15 seconds and chains extended at $72^{\circ} \mathrm{C}$ for 2 minutes, for 35 cycles. The primer set amplified a 652 bp segment of the cytochrome oxidase 1 mitochondrial gene. The amplified product was confirmed on $1.2 \%$ agarose gels stained with ethidium bromide. Amplified products were purified with QIAquick spin PCR purification kits 


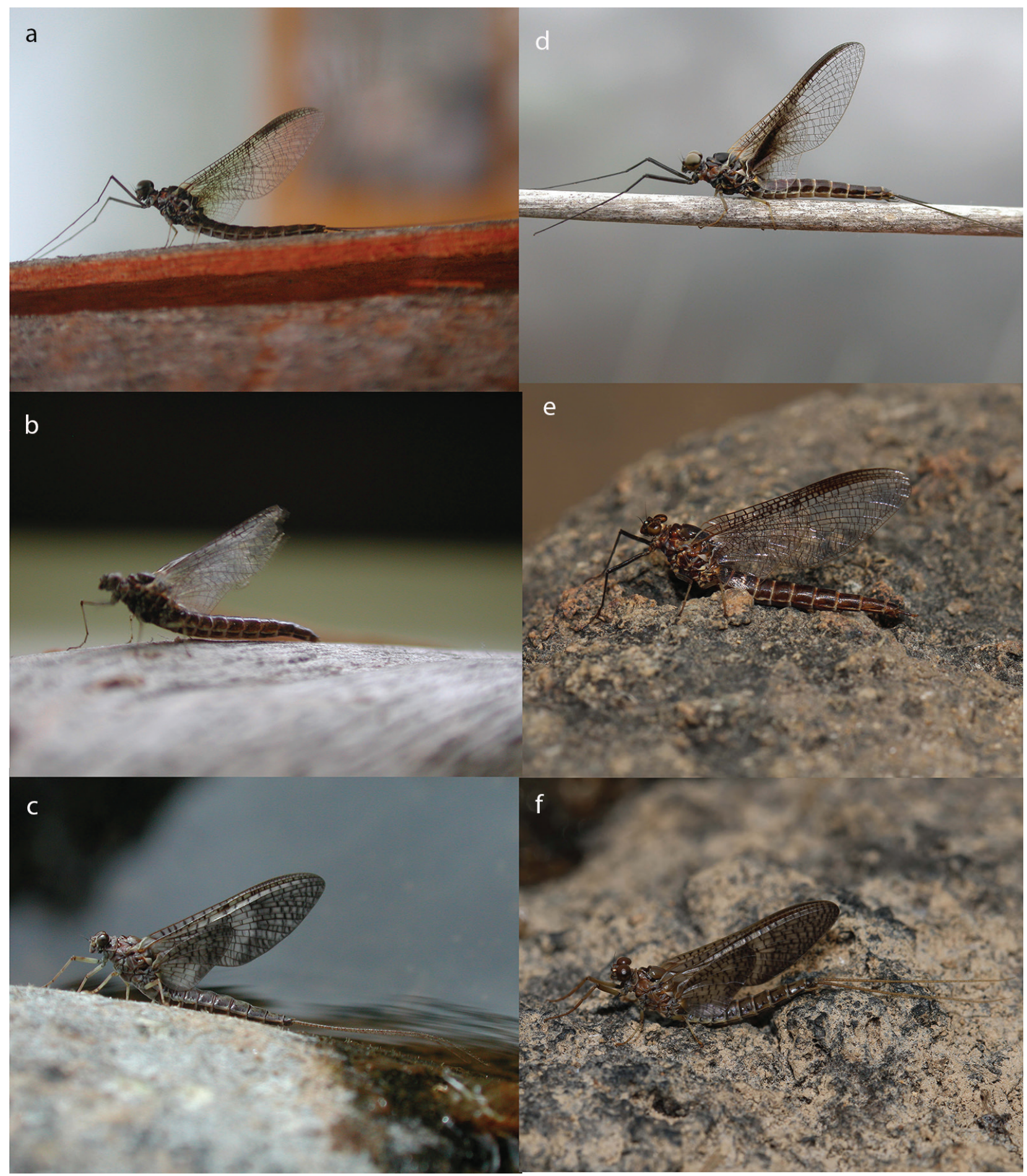

PLATE 1 - Male and female imagoes and sub-imago of the two Tasmanian species of Tasmanophlebia. All T. lotis (a, male imago; b, female imago; c, sub-imago) from Mountain River (SE Tasmania); (d) T. lacustris male imago from Little Pine Lagoon, and (e) female imago and (f) sub-imago from Ada Lagoon, both locations on the Tasmanian Central Plateau. Note that the forewings on the female imago of $T$. lotis (b) are damaged.

(QIAGEN INC., Chatsworth). Each PCR product was sequenced in both forward and reverse directions using Big Dye Terminator chemistry and run on an automated sequencer (ABI 3100 DNA capillary sequencer) according to the manufacturer's instructions. After primer sequences were removed, nucleotide sequence data were aligned and consensus sequences obtained using Seqman (DNA Star). Mega 7 (Kumar et al. 2016) was used to construct a molecular phylogeny using the Maximum Likelihood Method (Tamura \& Nei 1993). Relative time since separation for major branch points was determined using the RelTime method, following Tamura et al. (2012), and the probability of branching estimated by bootstrapping (500 replicates).

For the genetic analysis, DNA was extracted from one or more legs of sub-imago and nymphal specimens preserved 
for less than one year in ethanol (90\%). Samples of T. lotis were from three sites (Ringarooma River (one sub-imago), South Esk River (two sub-imagoes) and Mountain River (one sub-imago)); and those of T. lacustris were from two sites (Little Pine Lagoon (two sub-imagoes and a nymph) and an un-named lagoon near Pillans Lake (one nymph)). The mainland Tasmanophlebia sequenced were from the Kiewa River in Victoria (one sub-imago)) and the Swampy Plains River in NSW (one sub-imago and one nymph). Both specimens of T. lacus-coerulei sequenced were collected as sub-imagoes at the type locality, Blue Lake, Snowy Mountains, NSW. As an out-group for the genetic analysis, I also sequenced DNA extracted from a Coloburiscoides giganteus nymph (Coloburiscidae) collected in the Thredbo River, NSW.

Additional CO1 data for a pair of Tasmanian nymphs (from Benson Creek and the Weld River) and five mainland specimens (nymphs from the Rocky Valley River and Big Pats Creek, Victoria, and Thredbo River, NSW; two specimens, unspecified life history stage, from Fyans Creek, Victoria) were graciously provided by P. Suter. Analytic details are provided in Webb \& Suter (2011).

Photographs in the field were taken with a Nikon Coolpix and Canon 750D. Laboratory images were captured using a Leica MZ16FA microscope and Leica Application Suite 4.0 through a DFC310FX camera.

\section{TAXONOMY}

\section{Tasmanophlebia lotis sp. nov.}

Types: Tasmania: holotype, male imago, Mountain River, Tas. (42 56'44" S; $147^{\circ} 07^{\prime} 58^{\prime \prime} \mathrm{E}$ ), 9 March 2002, R. Thresher; paratypes: male and female imagoes, South Esk River below Mathinna, Tas. 12 March 2009; sub-imago, South Esk River below Mathinna, Tas., 28 December 2001; nymph, Hellyer River, Tas., 30 December 2015; nymph, Huon River, Tas., 29 December 2003. Specimens lodged at the Australian National Insect Collection (ANIC), Canberra, ACT

Etymology: lotis, based on lotic (Merriam-Webster dictionary definition: "living in actively moving water" (www.merriam-webster.com/dictionary), reflecting the preferred habit of the species (fast-flowing, cobble and gravel rivers). Contrasted with the Tasmanian still-water species $T$. lacustris, for which the species name is derived from lacustrine, defined as "living in or growing in lakes".

Description: Male imago (pl. 1): Overall black with white highlights on thorax. Abdomen dark grey dorsally, white ventrally with rufous spots. Wings clear with black veins and pigmented pterostigma. Forewing $9.48-10.5 \mathrm{~mm}$ long; hind wing 4.54-4.91 mm. Forelegs black, shading to grey distally; $10.4 \mathrm{~mm}$ long; ratio of segment lengths $2.52 ; 1.77 ; 1.97 ; 1.39 ; 1.24 ; 1.20 ; 0.57$. Other legs white with black pigment at joints. Tarsi dissimilar on all legs. Clasper three-segmented. Penis elongate and forked, with large openings dorsally at tips (pl. 2). Without external spines. Body length 11-12 mm; cerci $16 \mathrm{~mm}$. Appendix dorsalis reduced. Female imago (pl. 1): Overall reddish brown with black thorax. Wings clear. Body length 11-11.2 mm. Sub-imago (both sexes) (pl. 1): Overall grey, darker dorsally, with pale grey legs. Wings pale grey with darker grey veins, except for a conspicuous band of lighter grey on the forewing immediately behind area of overlap with hind wing. Hind wing also appears to have a pale section ventrally, but this is due principally to the contrast between where it does and does not overlap with the forewing. In life, the sub-imago appears to have a conspicuous oblique white band across the forewing. Body length $9.5-12.5 \mathrm{~mm}$.

Nymphs: Male and female similar, other than genitalia and eye size (smaller in females). Size range of mature individuals 8.9-12.9 mm body length, 12.9-17.9 $\mathrm{mm}$ total length. Nymph elongate, cylindrical when small but becoming increasingly dorsoventrally flattened with age/size. Overall colour mottled, grey to reddish brown, with conspicuous narrow bands on legs and cerci (pl. 3). Prominent paired pigment spots along ventral mid-line of abdomen, lacking in T. lacustris. Head small and round. Eyes black in female, black below and reddish brown above in males. Prominent white spot rimmed with black, forming an ocellus, between antennae. Antennae 9-segmented. Mouthparts generally similar to those described by Tillyard (1933) for T. lacus-coerulei and T. nigrescens and for a South Australian Tasmanophlebia spp. (as T. lacus-coerulei) by Suter (1986). However, the grinding plate on the right mandible of T. lotis appears to be narrower than that of other species, and the grinding plate of the left mandible is conspicuously falcate as compared to the straight-edged plates in T. lacustris and in the Tasmanophlebia sp. I collected in lowland rivers from Victoria and NSW (Tasmanophlebia sp. AV2, see below) and the slightly falcate plate in T. lacus-coerulei (pl. 4). Thorax widening posteriorly. Wing sheaths reaching to approximately $1 / 4$ length of the gills on large specimens. Gills on abdominal segments 1-4. First gills pigmented and broadly triangular. Gills 2-4 translucent, fringed with setae and bi-lobed. Abdomen in mature nymphs dorso-ventrally flattened with prominent lateral scutes. Prominent dorsal crest on abdominal segments 2-8.

Diagnosis and comparison with other species of Tasmanophlebia: As adults, T. lotis is smaller (length excluding cerci usually less than $12 \mathrm{~mm}$ ) than either the other Tasmanian species (T. lacustris, 12-15 $\mathrm{mm}$ ) or T. lacus-coerulei ( $>15 \mathrm{~mm})$, but similar in size to Tasamanophlebia spp. in Victoria, NSW, and, based on Suter (1986), South Australia. Although Tillyard (1933) and subsequently Riek (1955) distinguished T. lacuscoerulei from other Tasmanophlebia species on the basis of large size, in general, and large size of the forewing in particular, lengths of the fore and hindwings are the same linear function of body length in all species (fig. 1), but because the slopes of the relationships are less than $1.0(\mathrm{BL}$ vs FWL, slope $=0.68,95 \%$ CI $0.52-0.84$; BL vs HWL, slope $=0.47$, CI $0.37-0.57$ ), the wings of the small species and individuals (including $T$. lotis) are proportionately larger than those of larger species and individuals. Similarly, maximum width of the wings scales 


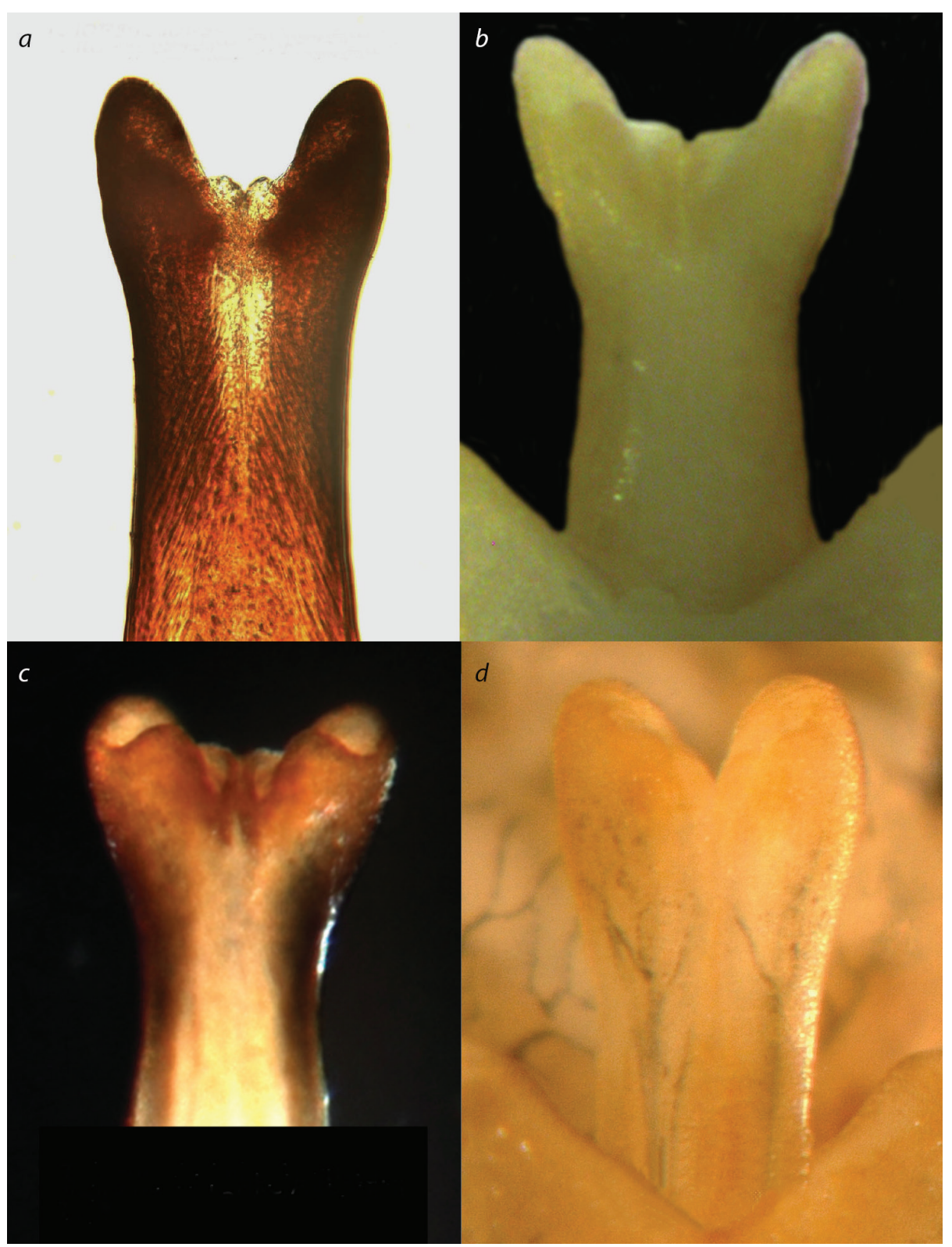

PLATE 2 - Genitalia (ventral views) of male imagoes of three described species of

Tasmanophlebia. (a) T. lotis, North West Bay River, Tasmania); (b) T. sp. AV2, Little Snowy River, Victoria; (c) T. lacustris, Lake Augusta, Tasmania; (d) T. lacus-caerulei, Blue Lake, NSW.

linearly with their length in the same way across species, but because of slopes that are again less than one (FW, slope $=0.33$, CI 0.26-0.39; HW, slope = 0.51, CI 0.39-0.64), small species/individuals have fore and hindwings that are proportionately wider than those of larger species/ individuals. No combination of wing ratios separates any of the four described taxa (as well as specimens from South Australia described by Suter, 1986) (fig. 1). Wing venation is also similar in the three described species and T. lotis, though the MA triad tends to originate distal to a line between the RS and MP triads in T. lotis but on or close to the line in T. lacustris (pl. 5). Tillyard (1933) suggested that the humeral projection of the costal margin of the hindwing of T. lacustris is more rounded and irregular than the angular projections of T. nigrescens or T. lacus-coerulei. However, this feature varies widely amongst individuals and the distinction is subtle, with slight irregularity often evident in both mainland Tasmanophlebia (sp. AV2) and T. lotis (pl. 5). The comparison is also confounded by apparent wide variability in the shape of the hindwing among the mainland specimens (pl. 5 and fig. 1c ).

As adults, the described species are more readily distinguished on the basis of colouration and genital morphology. Adult T. lotis and T. lacustris are broadly similar in body colouring (overall black or dark redbrown with pale annulations on the posterior edge of the abdominal segments, black thoraxes, generally darker dorsally than ventrally). Males can be distinguished on the basis of eye colour (brown dorsally in T. lotis, tan dorsally in T. lacustris) and by wing colour. The pattern of wing pigmentation is similar in the two species, but darker in T. lacustris. In T. lotis, the costal half of the hindwing is 


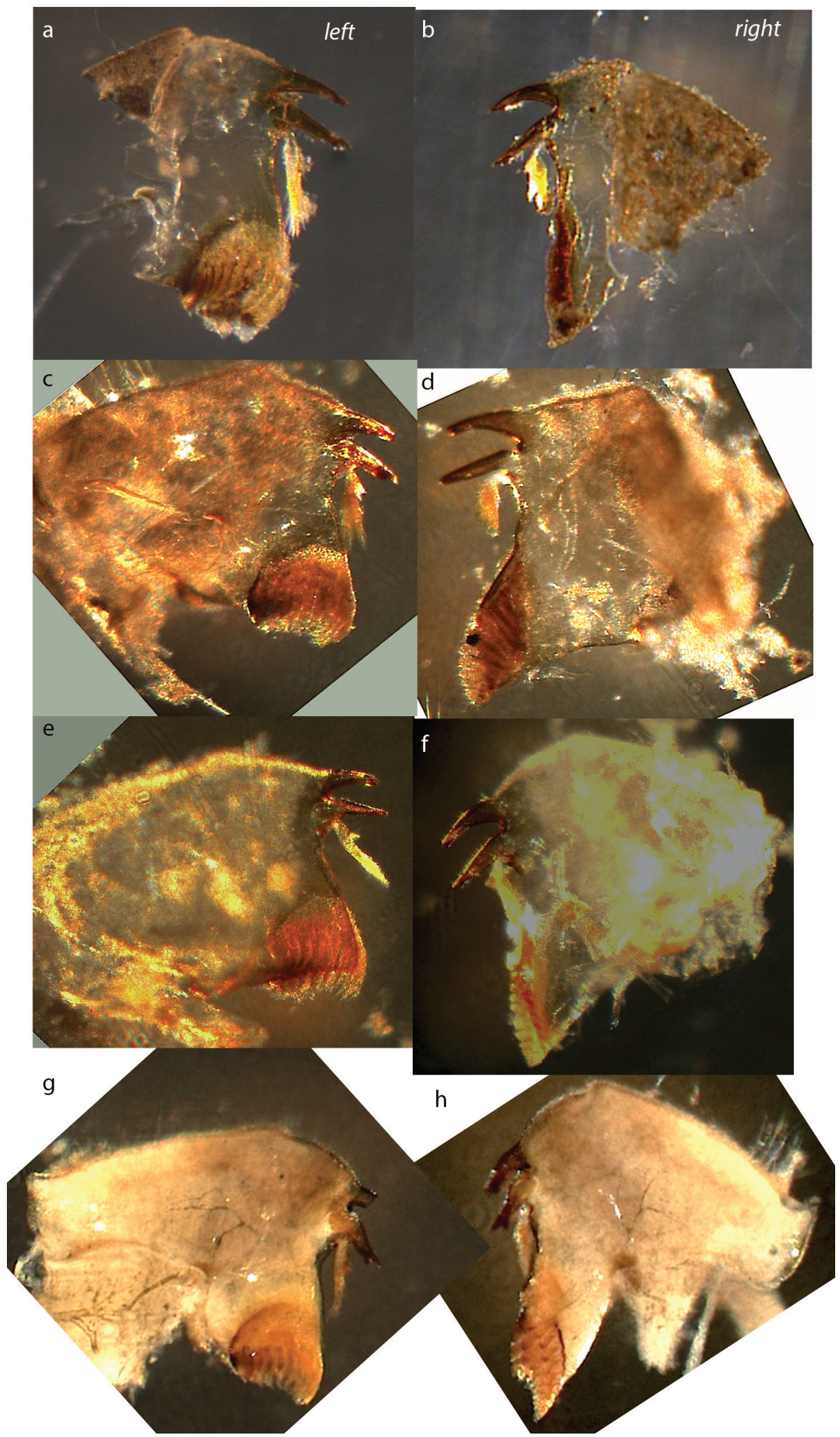

PLATE 3 - Left and right mandibles of (a, b) Tasmanophlebia lotis (Hellyer River, Tas.); (c, d) T. sp. AV2 (Swampy Plains River, NSW); (e, f) T. lacustris (Little Pine Lagoon, Tas.); and (g, h) T. lacus-coerulei (Blue Lake, NSW). 


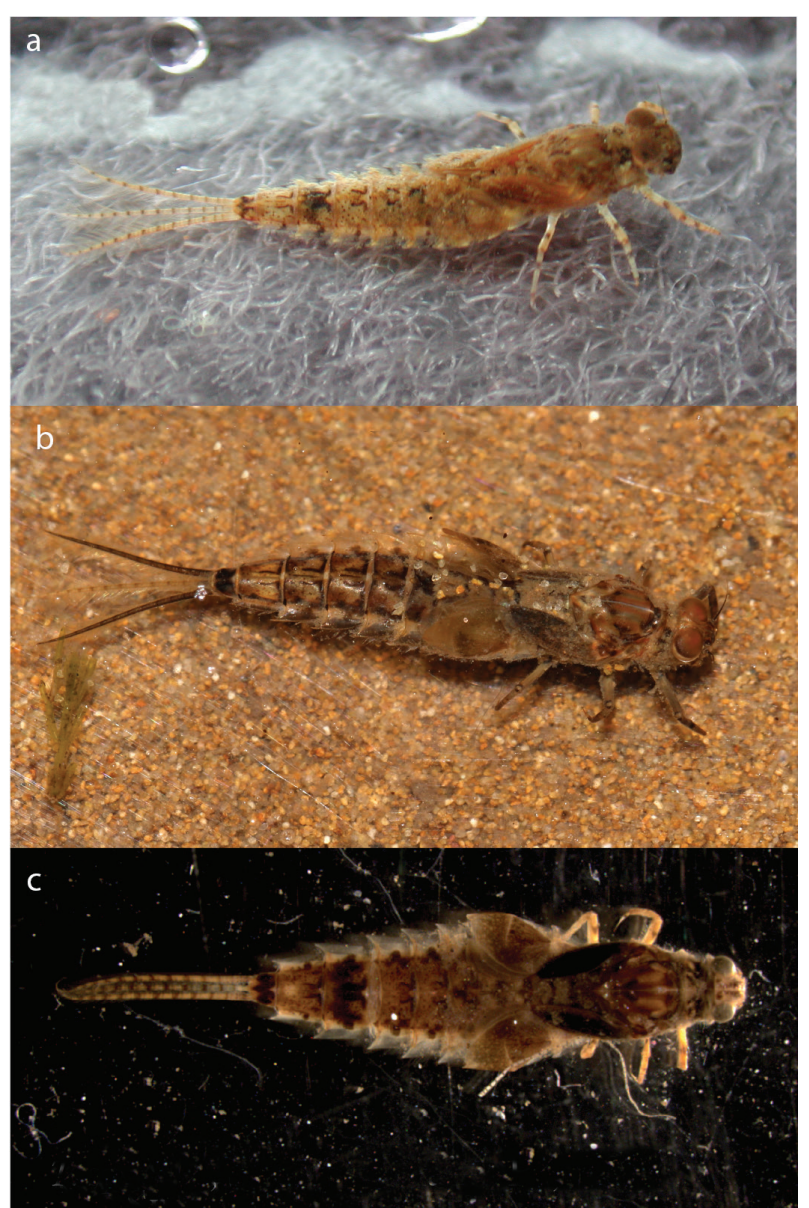

PLATE 4 - Nymphs of (a) Tasmanophlebia lotis, (b) T. lacustris (both live) and (c) T. sp. AV2 (specimen preserved in $90 \%$ ethanol).
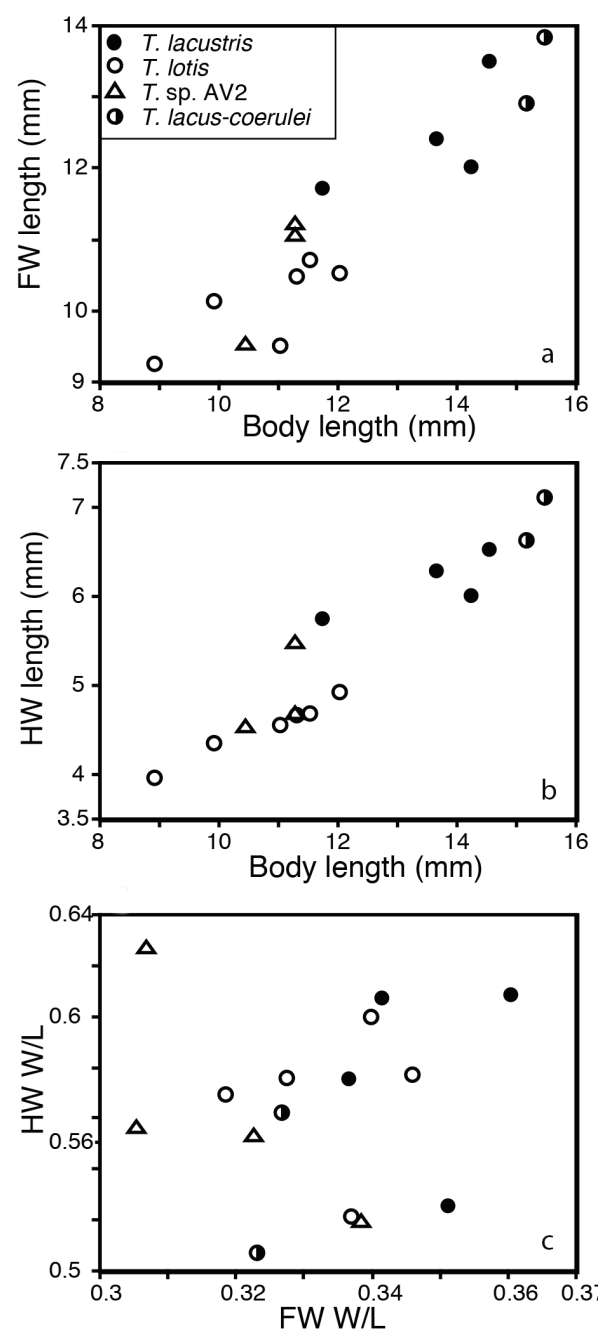

FIG. 1 - Relationships between forewing (FW) and hindwing (HW) dimensions (width and length) and body length in the Australian Tasmanophlebia spp.

fused along a long base and then dividing at the tip, looking like the letter "Y". The species differ in the shape of the genital lobes and apices. In an alcohol-preserved Tillyard specimen at the ANIC, the genitalia of a T. lacus-coerulei imago is broadly rounded at its apex and the lobes are narrowly divergent (pl. 2), consistent with Tillyard's (1933) description. In the other three species, the genital lobes are more strongly divergent. In T. lacustris, the wide angle is combined with bluntly rounded apices and large, round ventrally opening sperm ducts (pl. 2). Riek (1955) notes that the genitalia of male imagoes of $T$. nigrescens differ slightly from that of $T$. lacustris, but does not specify the differences. In both $T$. lotis and T. sp. AV2, the sperm duct openings are smaller and apices narrowly rounded (more so in T. sp. AV2 than T. lotis). The genital lobes of T. sp. AV2 are basally more widely divergent than in $T$. lotis and the tips straighter, such that the genitalia looks more like a "U" in T. sp. AV2 and a "V" in T. lotis (pl. 2).

Suter \& Webb (2012) provided a dichotomous key to the nymphs of two previously described species of Tasmanophlebia (T. lacus-coerulei not included), as well as four undescribed species. The latter group includes T. lotis

(as Tasmanophlebia sp. D). Principle diagnostic features
Male genitalia in the three described species, as well as T. lotis and T. sp. AV2, consist of a pair of hollow tubes 

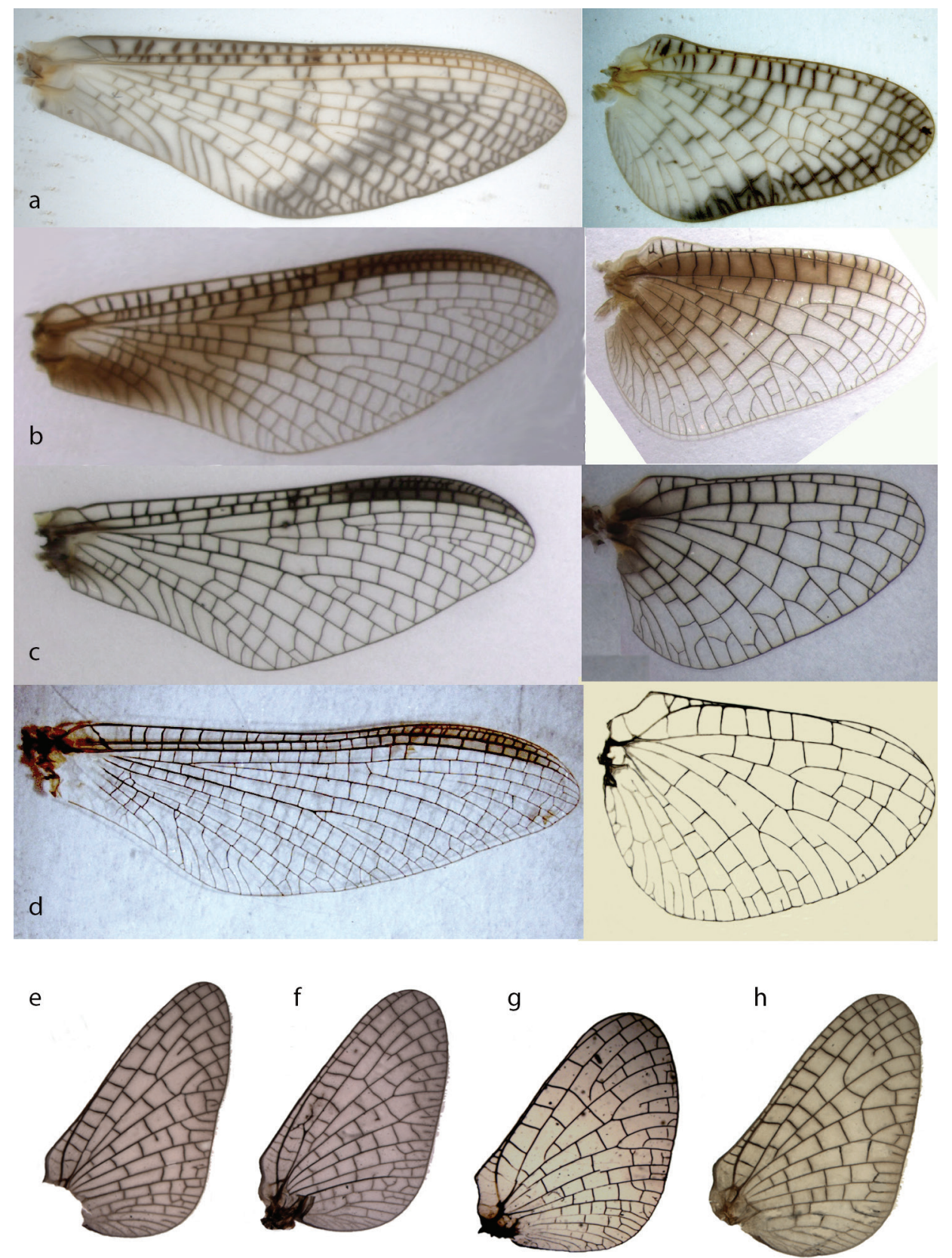

PLATE 5 - Top: Fore and hind wings of (a) Tasmanophlebia lacus-coerulei male sub-imago, Blue Lake, NSW; (b) T. lacustris male imago, Little Pine Lagoon; (c) T. Iotis male imago, South Esk River; and (d) T. sp. AV2 male imago, Swampy Plains River, NSW. Hind wings of male imago T. sp. AV2 from (e) the Swampy Plains River, NSW, (f) Kiewa River, Victoria, and (g) Ovens River, Victoria, compared with that of (h) T. lotis (South Esk River, Tasmania). 
are pigmentation and the extent of the abdominal dorsal crest. Consistent with Suter \& Webb (2012), among specimens I examined the crest in T. lotis spans segments $2-8$, as compared to T. lacustris, in which the dorsal spine on segment 6 is reduced and that on segments seven and eight very reduced or, more often, absent. Among other taxa, Suter \& Webb (2012) indicate T. nigrescens and undescribed sp. C both lack the spines on segments seven and eight that are present in T. lotis, and the undescribed sp. AV2 (and T. lacus-coerulei) has a prominent spine on segment 1 that is lacking in T. lotis. Diagnostic features between T. lotis and the undescribed mainland sp. AV1 are not yet available. Differences amongst $T$. lotis, $T$. lacustris, T. lacus-coerulei, and T. sp. AV2 in the shape of the mandibles are noted above.

Material examined: Nymph exuviae, Mountain R., Tas., 6 March 2002; F imago, nymph exuviae upper So. Esk R., 28 Dec 2001; F sub-imago, Styx R., Tas. 24 March 1988; nymph, So. Esk R., Mathinna, Tas., 7 Jan 2002; nymph, Brid R., Tas., 16 Oct 2004; F imago, Mountain R., Tas. March 2002; nymph Mountain R., Tas., 8 March 2002; F imago So. Esk R., Mathinna, 7 Jan 2002; nymph, upper Hellyer R., Tas., 30 Dec 2015; nymph exuviae,
Hellyer R., 6 April 2002; M imago, Ringarooma R., Derby, Tas., 5 Feb 2005; M imago, Nive R., Tas., 11 Feb 1986; M imago, Mountain R., Tas., 9 March 2002; M imago, Huon R., Tas., 16 Jan 2004; nymph, Huon R., Tas., 29 Dec 2003; nymph exuviae, Lake Dobson, Tas., 9 Feb. 2006; MoV specimens: nymphs, Douglas Creek, Tas.; nymphs, Isis R., Tas.

\section{GENETIC ANALYSIS}

CO1 sequence data for T. lotis, T. lacustris, T. lacuscoerulei and C. giganteus have been archived in Genbank (BankIT954250 Seq1 KX868576-Seq 10 KX868585). Differences in nucleotide sequences among the examined oniscigastrid species were slight. Among the specimens examined, nucleotide sequences averaged 707 bases, which combined with the Suter $\&$ Webb material to produce a consensus CO1 sequence of 643 bases. The nearestneighbour tree produced four closely related, but distinct groupings of specimens (fig. 2). The phylogeny suggests two major branch points: T. lacus-coerulei is a sister group to the other three species of Tasmanophlebia, separating

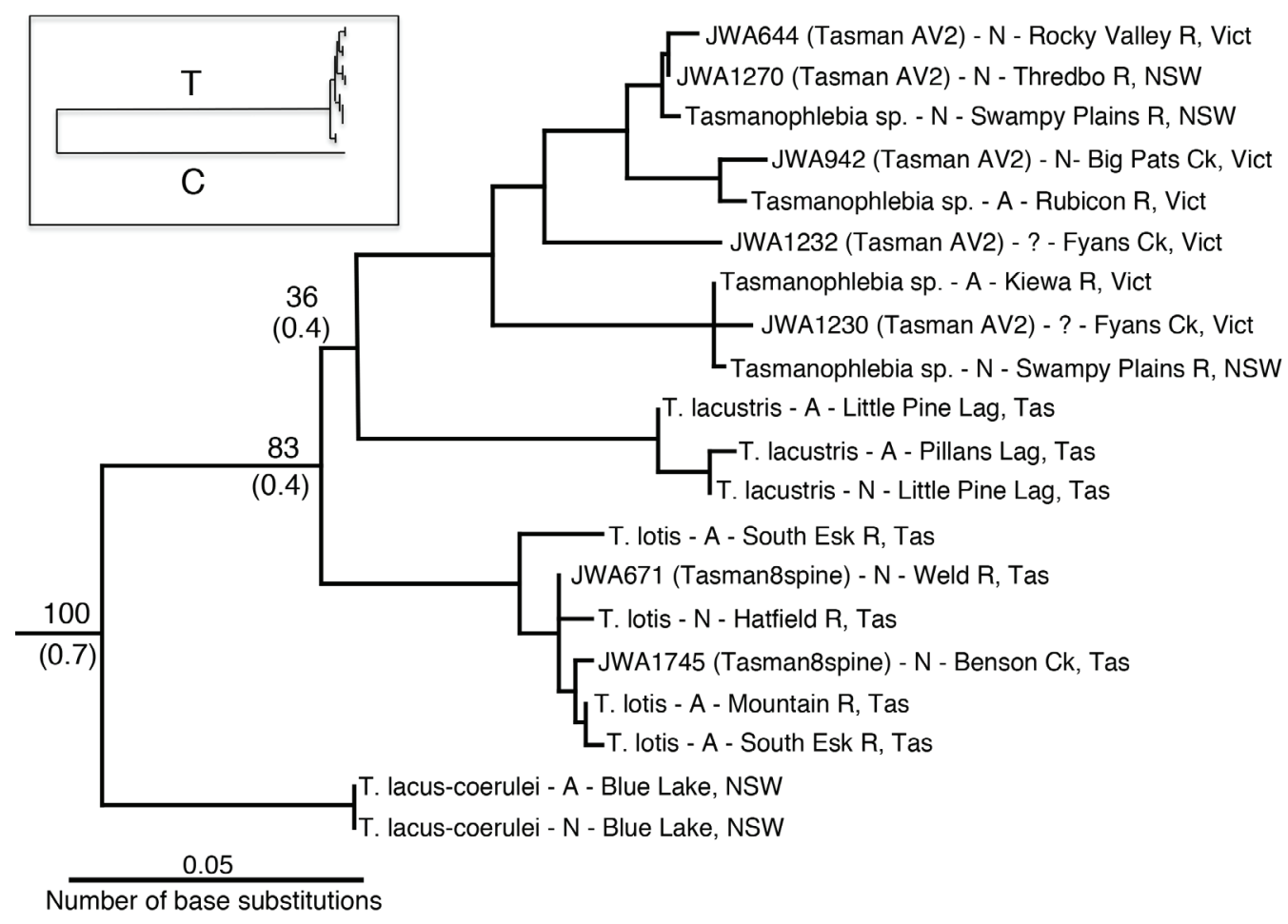

FIG. 2 - Molecular phylogenetic analysis (CO1) time tree based on the Maximum Likelihood method, for Tasmanophlebia specimens collected in Tasmania, Victoria and NSW, plus as an out-group, a nymph of Coloburiscoides giganteus (box). Suter \& Webb specimens are indicated by specimen number (JWA...); they identified their mainland specimens as $T$. sp AV2. Numbers at the major branches indicate the proportion of events in a bootstrap test of phylogeny (500 replicates) in which the two branches clustered together and, in parentheses, the relative time of separation. The tree is drawn to scale, with the branch lengths measured in the relative number of substitutions per site. $\mathrm{A}=$ adult (sub-imago), $\mathrm{N}=$ nymph, ? = life history stage of specimen not specified. 
earliest in the phylogeny, followed by a nearly, if not actually, concurrent separation of T. lotis and T. lacustris from the other sampled mainland Tasmanophlebia. The specimens I collected in lowland rivers in Victoria and NSW, and illustrate in the plates, group with and appear to be conspecific with Suter \& Webb’s (2012) Tasmanophlebia sp. AV2 (fig. 2). Genetically, T. lotis is most similar to T. sp. AV2 (average number of base substitutions 0.092) and most different from T. lacus-coerulei (0.117). Differences within species are slight for T. lacus-coerulei (mean number of base substitutions 0 ), low for T. lacustris and T. lotis (0.01 and 0.014 , respectively) and much higher for T.AV2 (0.054). As expected from a genetic analysis, adults and nymphs group together within species. Also as expected, the specimen of Coloburiscoides giganteus used as an outgroup for the analysis is clearly separated genetically from Tasmanophlebia.

\section{ECOLOGY AND BEHAVIOUR}

The geographic and habitat distributions of the two Tasmanian species appear to be largely, if not completely, non-overlapping. In extensive sampling over Tasmania spanning the past 28 years, I have found T. lacustris only in lakes, ponds and pools in rivers on and close to the Tasmanian Central Plateau (fig. 3), where it is abundant. The exception is a single specimen collected at Arthurs Lake, a lower-altitude impoundment near the Central Plateau, in 1987. I have not seen the species there since. Tillyard (1935) reported T. lacustris from Lake Echo and, abundantly, Penstock Lagoon, also mid-altitude impoundments, based on collections in the 1930s and 1940s, but I have not found the species at either location. Riek (1955) also reports the species present in Lake Dobson, in the sub-alpine highland of Mount Field National Park. However, nymph exuviae collected on rocks along the margin of Lake Dobson in 2012 are attributable to T. lotis, based on abdominal spination. Otherwise, T. lotis is widely distributed in usually fast-flowing, cobble and gravel-filled streams and rivers in lowland Tasmania (fig. 3). Its presence in Lake Dobson reflects a preference for this habitat; although a "lake", Lake Dobson is essentially a large cobble pool at the head of a stream at Mount Field. In the same way, the presence of T. lacustris in slow-flowing pools and pondages in rivers on the Central Plateau reflects its essentially lacustrine habitat preferences. Neither species appears to be present in the rocky, sub-alpine ponds and lakes in the Hartz Mountain National Park (SE Tasmania), based on the absence of the usually conspicuous nymph exuviae during mid- and late summer collecting trips that span several years.

Tasmanophlebia lacustris nymphs are conspicuous and often very abundant in soft sediment habitats on the Central Plateau, where they form irregular lines in the sediment as they plough through it while feeding. Disturbed, they swim vigorously for short distances by undulating their bodies vertically. Not surprisingly, given their abundance, they are a major component of trout diets in these lakes. Nymph exuviae are extremely common on emergent rocks, vegetation, tree branches and other debris along the edges of the pondages, though the nymphs also frequently emerge by crawling directly onto muddy lake margins, where they transform into sub-adults. Imagoes have been observed in mating swarms at Little Pine Lagoon, Tin Hut Lagoon, Lake Ada and Ada Lagoon, in all cases in mid- to late summer (January to March) and late in the afternoon or in the evening. This seasonality is narrower than reported for alpine NSW Tasmanophlebia spp. by Campbell (1986), with adults recorded from September to March; Campbell suggested there may be more than one generation per year. Adult T. lacustris are relatively weak flyers, and occur in groups of approximately 10-30 individuals drifting back and forth horizontally around and over prominent bushes and other landmarks. At Tin Hut Lagoon and Lake Ada, the swarms were tens
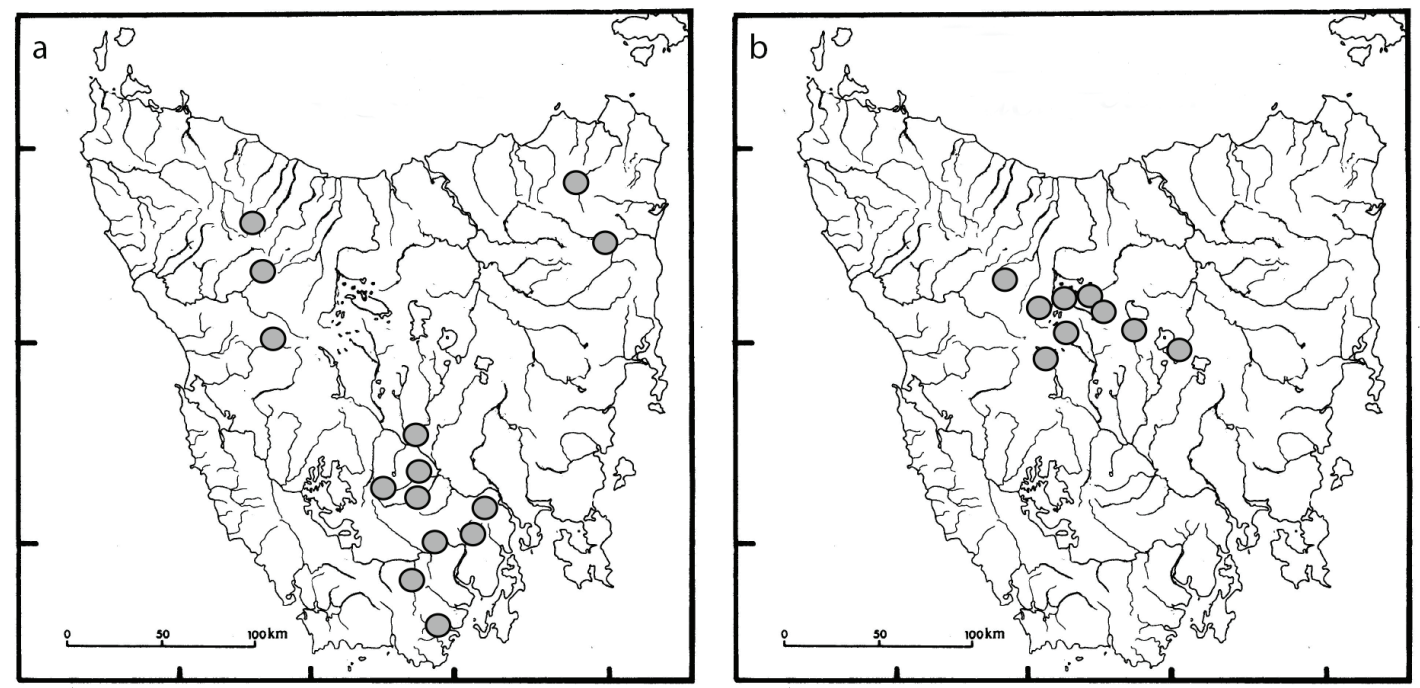

FIG. 3 - Locations where the author has collected (a) Tasmanophlebia lotis and (b) T. lacustris in Tasmania. 
of metres from the shorelines. At dusk on 22 January 2016, I observed hundreds of swarms and thousands of T. lacustris "spinning" over bushes up to 40-50 m back from the edges of Lake Ada and Ada Lagoon. On several occasions, I have also found numerous spent female $T$. lacustris along lake margins early in the morning, consistent with dusk and nocturnal mating and egg-laying.

I have observed swarming behaviour of T. lotis on only one occasion, on 13 March 2009, along the rocky edges of the South Esk River near Mathinna (NE Tasmania). Solitary and small groups of adult males were seen flying in short horizontal excursions close to the ground, occasionally up to about $1 \mathrm{~m}$ high, along the shoreline in late morning and early afternoon. As in T. lacustris, they were noted to be relatively weak fliers, easily collected. Adults and sub-adults of the species are recorded in my field records from late December to early April, with most observations in February. The behaviour of the nymphs is similar to that of T. lacustris, typically observed "bulldozing" through soft sediments. Emergence, as in other species in the genus (Campbell 1986), takes place by the nymph crawling out onto rocks and debris.

\section{DISCUSSION}

A comparison of the morphology and meristics of the Tasmanian lowland material with published descriptions, museum specimens and live caught material of T. sp. AV2 from Victorian and NSW rivers indicated broad overlap in most features between the mainland and Tasmanian samples, but also differences in hind wing shape (more triangular in Tasmania), mandible (narrower and more pointed grinding plate) and colour of the nymph (a characteristic spotting pattern on the ventral abdomen of Tasmanian specimens, uncommon among mainland samples). These differences suggested at least sub-speciation between the Tasmanian and mainland specimens. This hypothesis was tested by a CO1 genetic analysis, which was expanded to include $T$. lacustris and T. lacus-coerulei. The results strongly suggest the Tasmanian lowland specimens constitute a species separate from, but ecologically and morphologically similar to mainland, low elevation Tasmanophlebia spp.

Riek (1955) reported three species of Tasmanophlebia in Australia, two (T. lacus-coerulei and T. nigrescens) found on the Australian mainland and one (T. lacustris) endemic to highland areas of Tasmania. He subsequently (1970) listed four species (see also Hubbard \& Campbell 1996), the addition possibly relating to a specimen subsequently collected in South Australia by Suter (1986). Riek (1955) also noted the similar morphology of $T$. nigrescens and $T$. lacustris, and speculated that the insects may be conspecific. Most recently, Suter \& Webb (2012) suggested at least six species of Tasmanophlebia, based on nymph morphology and distributions, two of which occur in Tasmania.

The genetic analysis confirms $T$. lacus-coerule $i$ is a sister clade to the other members of the genus, but also documents roughly equivalent levels of separation, based on nucleotide substitutions, amongst T. lotis, T. sp. AV2, and T. lacustris.
The separation between the latter three species is reinforced by slight but consistent morphological differences among the three both as adults and nymphs and, for the Tasmanian pair, prominently non-overlapping habitat preferences. The genetic, morphological and ecological evidence supports an hypothesis of reproductively isolated populations. The first two lines of evidence also suggest significant heterogeneity among mainland T. sp. AV2, in the form of relatively high levels of genetic diversity among specimens and conspicuous differences in hindwing shape. The South Australian specimens of Tasmanophlebia reported by Suter (1986) appear to be T. sp AV2, based on a prominent dorsal spine on the first abdominal segment.

More generally, identification of $T$. lotis as a valid species is consistent with the suggestion of Hughes et al. (2011) that genetics would reveal a number of such cryptic taxa among Australian mayflies. The nearly, if not actually, identical relative time to separation between T. sp. AV2, T. lacustris and T. lotis suggests a split between the mainland riverine species and a Tasmanian population that quickly separated into a highland, lentic and lower elevation riverine species. Lack of a calibration date for the genetic analysis precludes estimating actual divergence times at this stage, but the differences amongst the Tasmanophlebia species parallel genetic (CO1) evidence of similar pairs of mayfly species in the genus Offadens (Baetidae) that are also found on both sides of Bass Strait (Webb \& Suter 2011). The magnitude of sequence differences in the Baetids suggests separation of these sister taxa well before the Holocene flooding of Bass Strait following deglaciation (Webb \& Suter 2011), which also could be the case in Tasmanophlebia.

\section{ACKNOWLEDGEMENTS}

I thank D. Abbott, N. Bax, R. Shine, A.C., A.G. and H.E. Thresher for assistance in field collections, R. Griffin for trout gut contents samples, P. Grewe, J. Robson, S. Ball and J. Van de Kamp for invaluable assistance with the genetic analysis, and P. Suter and J. Webb for sharing their CO1 data for mainland and Tasmanian specimens. This paper benefited substantially from comments by P. Suter and J. Dean, both of whom are gratefully acknowledged.

\section{REFERENCES}

Campbell, I.C. 1986: Life histories of some Australian Siphlonurid and Oligoneurid mayflies (Insecta: Ephemeroptera). Australian Journal of Marine and Freshwater Research 37: 261-288.

Folmer, O., Black, M., Hoeh, W., Lutz, R. \& Vrijenhoek, R. 1994: DNA primers for the amplification of mitochondrial cytochrome c oxidase subunit 1 from diverse metazoan invertebrates. Molecular Marine Biology and Biotechology 3(5): 294-299.

Grewe, P., Krueger, C.C., Aquadro, C.F., Bermingham, E., Kincaid, H.L. \& May, B. 1993: Mitochondrial DNA variation among lake trout (Salvelinus namaycush) strains stocked into Lake Ontario. Canadian Journal of Fisheries and Aquatic Sciences 50: 2397-2403. 
Hebert, P.D.N., Ratnasingham, S. \& deWaard, J.R. 2003: Barcoding animal life: cytochrome $\mathrm{c}$ oxidase subunit 1 divergences among closely related species. Proceedings of the Royal Society of London B (Suppl.): DOI 10.1098/ rsbl.2003.0025.

Hubbard, M.D. 1990: Mayflies of the World, A catalog of the family and genus group taxa (Insecta: Ephemeroptera). Flora \& Fauna Handbook No. 8, Sandhill Crane Press, Gainesville, Fla. USA: 119 pp.

Hubbard, M.D. \& Campbell, I.C. 1996: Catalogue of the Australian mayflies, recent and fossil (Insecta: Ephemeroptera). Special Publications of the Australian Society of Limnology 11: 43 pp.

Hughes, J.M., Huey, J.A., McLean, A.J. \& Baggiano, O. 2011 : Aquatic insects in eastern Australia: a window on ecology and evolution of dispersal in streams. Insects 2: 447-461.

Kumar, S., Stecher, G. \& Tamura, K. 2016: MEGA7: molecular evolutionary genetics analysis version 7.0 for bigger data sets. Molecular Biology and Evolution 33: 1870-1874.

Riek, E.F. 1955: Revision of the Australian mayflies (Ephemeroptera). 1. Subfamily Siphlonurinae. Australian Journal of Zoology 3: 266-280 plus plate.

Riek, E.F. 1970: Ephemeroptera (mayflies). In: The Insects of Australia. Melbourne University Press, Parkville, Victoria, Australia: 224-240.

Scholes, D. 1961: Fly-fisher in Tasmania. Melbourne University Press, Parkville, Victoria, Australia: 208 pp.

Suter, P.J. 1980: The taxonomy and ecology of the Ephemeroptera (mayflies) of South Australia. Unpublished PhD thesis, University of Adelaide.

Suter, P.J. 1986: The Ephemeroptera (mayflies) of South Australia. Records of the South Australian Museum 19: 339-397.

Suter, P.J. \& Webb, J. 2012: Key to the mature nymphs of Tasmanophlebia (Ephemeroptera: Oniscigastridae). Paper presented at the Taxonomy Research and Information Network (TRIN) Taxonomic Workshop held 31 January-1 February 2012, La Trobe University, Albury-Wodonga, January 31-1 February.

Tamura, K., Battistuzzi, F.U., Billing-Ross, P., Murillo, O., Filipski A. \& Kumar, S. 2012: Estimating divergence times in large molecular phylogenies. Proceedings of the (US) National Academy of Sciences 109: 19333-19338.

Tamura, K. \& Nei, M. 1993: Estimation of the number of nucleotide substitutions in the control region of mitochondrial DNA in humans and chimpanzees. Molecular Biology and Evolution 10: 512-526.

Tillyard, R.J. 1921: A new genus and species of mayfly (order Plectoptera) from Tasmania, belonging to the family Siphlonuridae. Proceedings of the Linnean Society of NSW 46: 409-412.

Tillyard, R.J. 1933: The mayflies of the Mount Kosciusko region. 1. (Plectoptera). Proceedings of the Linnean Society of NSW 58: $1-32$.

Tillyard, R.J. 1935: The trout food insects of Tasmania, Part II - a monograph of the mayflies of Tasmania. Proceedings of the Royal Society of Tasmania 1935: 23-59 plus plate.

Webb, J.M. \& Suter, P.J. 2011: Identification of larvae of Australian Baetidae. Museum Victoria Scientific Reports 15: 1-39.

\section{Appendix}

\section{OTHER MATERIAL EXAMINED}

T. lacustris: $\mathrm{M}$ and $\mathrm{F}$ imagoes and sub-imagoes, Little Pine Lagoon, Tas., 16 Jan 2003; $\mathrm{M}$ and $\mathrm{F}$ imagoes, nymphs Little Pine Lagoon, 3 Jan 2003; nymphs, unnamed pond near Pillans Lake, 24 Nov 2005; M and F sub-imagoes and imagoes, Ah Chees Lake, Tas., Jan 1988; nymph, Carter Lakes, Tas., 3 Feb 2004; nymph exuvia, Lake St Clair, Tas., 10 March 2016; $\mathrm{M}$ and $\mathrm{F}$ sub-imagoes and imago, First Bar Lake, Tas., 28 Jan 1998; nymph, Pine Tier Lagoon, Tas., 1 March 1987; F imago, Lake Augusta, Tas., 5 March 1990; nymph exuvia, Lake St Clair, Tas., 10 Jan. 2005; F sub-imago and nymph exuviae, Lake St Clair, 23 Feb. 1983; M sub-imago, Arthurs Lake, Tas., 1 March 1987; F imago, Lake Augusta, Tas., 8 March 1992; M and F subimagoes, nymphs, Deep Lake, Tas., 27 Jan 1991; M and F imago, Lake St Clair, Tas., 6 March 1988; F sub-imago Kay Lagoon, Tas., 22 Nov 1994; M and F sub-imagoes, Great Lake, Tas., 29 Jan 1995; M imago, Lake Augusta, Tas., 1 March 1992; M and F sub-imago, Lake Augusta, Tas., 26 Dec. 1982; M sub-imago, Christy's Creek, Tas., 9 Feb 2002; nymph exuviae, Ouse R. above Lake Augusta, Tas., 2 Feb. 2007.

T. sp. AV2: F imago and nymph, Swampy Plains R., NSW, 23 Feb 2006; M and F sub-imago, Ovens R., Vict., 23 Feb 2006; M imago and nymph exuviae, Rubicon R., Thornton, Vict., 24 Feb 2006; nymph exuviae, Kiewa R., Tawonga, Vict., 23 Feb 2006; MoV specimens: nymphs, Yarra R., Vict.; nymphs, Thougla Creek, Vict.; nymphs, Goulburn R., Vict.; nymphs, Watts R., Vict.; nymphs, Little Snowy Creek, Vict.; M imago, Little Snowy R., Eskdale, Vict., 20 Dec 1982; nymphs, Indi R., NSW. ANIC specimens: M and F sub-imagoes, Bolairo R., NSW, 13 Dec 1974; F sub-imago, Spencers Creek, NSW, 28 Jan 1930.

T. lacus-coerulei: $\mathrm{M}$ and $\mathrm{F}$ sub-imagoes and nymphs, Blue Lake, NSW, 22 Feb 2006; F sub-imago, Betts Creek, NSW, 22 Feb 2006. ANIC specimens: F imago and F sub-imago, Blue Lake, NSW; M sub-imago, Blue Lake, NSW. 
